УДК 330.16 .12

DOI: https://doi.org/10.37320/2415-3583/16.5

Нестеренко С.C.

кандидат економічних наук, доцент

Відкритий міжнародний університету розвитку людини «Україна» ORCID: https://orcid.org/0000-0001-9090-3470

\title{
АКТУАЛІЗАЦІЯ ПРОЦЕСУ ПРИСКОРЕНОГО ФОРМУВАННЯ ВІДНОСНИХ КОНКУРЕНТНИХ ПЕРЕВАГ РЕГІОНІВ УКРАЇНИ
}

\begin{abstract}
У статті досліджено теоретико-прикладні засади формування конкурентних переваг мезорівня національної економіки в аспекті прискорення формування відносних конкурентних переваг регіонів України. Сформовано структурну ієрархію відносних конкурентних переваг у межах національної економіки. Проведено аналіз щзодо забезпечення капітальних інвестицій за регіонами Украӥни в розрізі промисловості та основних джерел їх формування. Розроблено структурну модель визначення регіональних конкурентних переваг. Доведено, щзо формування і розвиток регіональних виробничих комплексів сприяє реалізації територіальних конкурентних переваг, щьо стимулює економічне зростання регіонів на основі їх активного входження в систему світового господарства, а також міжрегіональний поділ соціально-виробничих функцій між регіонами.
\end{abstract}

Ключові слова: конкурентні переваги, регіональні виробничі комплекси, мезорівень, капітальні інвестиції, промисловість, регіональне виробництво.

Постановка проблеми. Теоретична і практична актуальність спеціального розгляду ступеня стійкої конкурентоспроможності тієї чи іншої національної економіки особливо посилюється процесом глобалізації світового економічного розвитку. Це надає пріоритету таких питань, як зміст, індикатори та параметри конкурентоспроможності макроекономічної системи країни. Більше того, тільки комплексне вивчення названих питань може допомогти виявити стратегічні напрями прискореного зростання національної економіки й економічного потенціалу макроекономічного регулювання інструментами монетарної і фіскальної політики. Основи загальної теорії конкурентоспроможності національної економіки особливо інтенсивно розроблялися в останні десятиліття. Актуалізація питань впровадження стратегічно орієнтованих інноваційних методів підвищення конкурентоспроможності регіонів привертає особливу увагу дослідників до напрямів територіальної конкуренції в умовах глобалізації економіки, урбанізації та активного поширення інформаційно-комунікаційних технологій, по суті, факторів і циклічного характеру підвищення територіальної конкурентоспроможності.

Аналіз останніх досліджень і публікацій. Наукові аспекти щодо формування та зростання рівня конкурентоспроможності регіонів представлено в роботах: Т. Безверхнюк, В. Білика, Н. Бутко, Б. Данілішина, Дегтярьова, С. Іщука, Н. Калюжної, Дж. Керона, Н. Метеленко, Ю. Перського, О. Ряби. Але у цих публікаціях недостатня увага приділяється питанням розвитку й автономізації регіональних виробничих комплексів, які визначають ступінь використання внутрішньорегіональних джерел зростання ефективності та прискорення темпів соціально-економічної динаміки території.

Мета статті полягає у дослідженні теоретико-прикладних засад формування конкурентних переваг територій та розробленні методичних рекомендацій щодо зростання рівня ефективності функціонування регіональних виробничих комплексів у межах національної економіки.
Виклад основного матеріалу. У сучасній економічній теорії національної (регіональної) конкурентоспроможності для оцінки і розрахунків використовуються показники, які називають «індексами конкурентоспроможності». Вони поширюються на підсистему факторів економічного зростання, що емпірично фіксуються. Зростання рівня національної конкурентоспроможності розраховується за динамікою технологічного індексу, індексу громадських інститутів та індексу макроекономічного розвитку. Регіональні виробничі комплекси сприяють раціональному розподілу та привласненню територіальних ресурсів і доходів і тим самим забезпечують зростання конкурентоспроможності регіональної економіки. Звідси випливає, що високоефективна регіональна економічна політика включає як невід'ємний інструмент спеціальне регулювання відносин між регіональними виробничими комплексами з метою врахування інтересів суб'єктів, що утворюють їх.

Авторська концепція проблеми взаємозумовленості конкурентних переваг території й ефективного функціонування регіональних виробничих комплексів полягає у визнанні та обгрунтуванні тези, згідно 3 якою нині розвиток регіональної економіки стає пріоритетом і визначається умовами і способами реалізації конкурентних переваг названих комплексів (у межах окремого регіону) [1]. 3 огляду на те, що об'єктивні i кон'юнктурні умови функціонування та розвитку регіональних виробничих комплексів можуть істотно змінюватися навіть у короткострокових інтервалах (відображаючи динаміку співвідношення і спрямованості впливу внутрішньо- i надрегіональних чинників), слід визнати обгрунтованим висновок про те, що співвідношення названих чинників буде визначати в довгостроковій перспективі конкурентні переваги регіонів, у цьому аспекті зростає значимість реалізації економічного потенціалу регіональних виробничих комплексів, включаючи перехід до стимулюючого становлення таких комплексів податковими і кредитними ставками, розвиток конкурентного середовища у сфері активізації непрямих форм бюджетування, i навіть 
у сфері формування сприятливого інвестиційного клімату [2].

Формування і розвиток регіональних виробничих комплексів сприяє реалізації територіальних конкурентних переваг, що стимулює економічне зростання регіонів України на основі їх активного входження в систему світового господарства. Міжрегіональний поділ соціально-виробничих функцій між регіонами представлено в табл. 1.

Формування регіональних виробничих комплексів відображає об'єктивні відмінності регіонів, які представлені сукупністю цих комплексів, інтегровано представляють територіальні конкурентні переваги, особливо складні варіанти виникають у разі межкомплексної взаємодії (коопераційна взаємодія виробничих комплексів одного регіону з виробничими комплексами іншого регіону) (рис. 1).

Сучасна територія як локалізована система виробництва трансформувалася в систему територіально сполучених регіональних виробничих комплексів на базі інтеграції підприємницької, інвестиційної та фінансової інфраструктури регіону. При цьому важливо відзначити, що кожен регіональний виробничий комплекс формується на основі базових ресурсних елементів регіону, що сприяє реалізації об'єктивних конкурентних переваг.

У сучасному світі відокремлення й існування регіональної економіки як особливої підсистеми національного господарства правомірно тією мірою, якою вона забезпечує ефективне функціонування виробничих комплексів, що утворюють цю регіональну економіку. Іншими словами, тільки наявність у регіональній організації виробництва деяких специфічних («регіональних») конкурентних переваг перетворює регіональну організацію національної економіки на об'єктивний складник механізму всілякої реалізації виробничого потенціалу країни [4, с. 45]. Не менш справедливий і висновок, що випливає звідси: регіональна економіка тією мірою конкурентоздатна, в якій їй удається забезпечити і реалізувати конкурентні переваги, сформовані iii регіональними виробничими комплексами.

Основними параметрами, що характеризують відносні конкурентні переваги регіонів, виступають рівень витрат виробництва регіонального валового продукту і професійна кваліфікація масового працівника. Похідними параметрами відносних конкурентних переваг регіону слід уважати: ступінь цінової та технологічної диференціації валового регіонального продукту, ступінь забезпеченості регіону базовими факторами виробництва, перш за все природними ресурсами, робочою силою і капітальними інвестиціями [5, с. 39-40]. Загальний обсяг капітальних інвестицій за регіонами України представлено в табл. 2.

Таким чином, відносні конкурентні переваги за показником капітальних інвестицій за регіонами України є сумою основних та похідних природно-господарських параметрів, якими характеризується регіональна економіка. У цій площині ми можемо дослідити розпо-

Таблиця 1 - Структурна ієрархія відносних конкурентних переваг у межах національної економіки

\begin{tabular}{|l|l|l|l|}
\hline \multirow{2}{*}{ Рівні господарства } & \multicolumn{3}{|c|}{ Національна господарська система } \\
\cline { 2 - 4 } Макрорівень & характер і етика рівня & \multicolumn{1}{|c|}{ функція } & \multicolumn{1}{c|}{ форма реалізації } \\
\hline Мародне господарство & $\begin{array}{l}\text { Забезпечення умов відтворення } \\
\text { народонаселення країни i } \\
\text { громадських інститутів }\end{array}$ & $\begin{array}{l}\text { валовий національний продукт } \\
\text { у натуральному вираженні або } \\
\text { вартісному вимірі }\end{array}$ \\
\hline Мікрорівень & $\begin{array}{l}\text { галузі, сфери, } \\
\text { регіональні і комплекси }\end{array}$ & $\begin{array}{l}\text { відтворення регіонального } \\
\text { продукту }\end{array}$ & $\begin{array}{l}\text { валовий продукт міжгалузевих } \\
\text { регіональних виробничих комплексів }\end{array}$ \\
\hline $\begin{array}{l}\text { підприємства, що } \\
\text { створюють кінцевий } \\
\text { продукт }\end{array}$ & $\begin{array}{l}\text { забезпечення локального попиту і } \\
\text { пропозиції }\end{array}$ & $\begin{array}{l}\text { товари і послуги певного локального } \\
\text { ринку }\end{array}$ \\
\hline
\end{tabular}

Джерело: сформовано автором на основі [3]

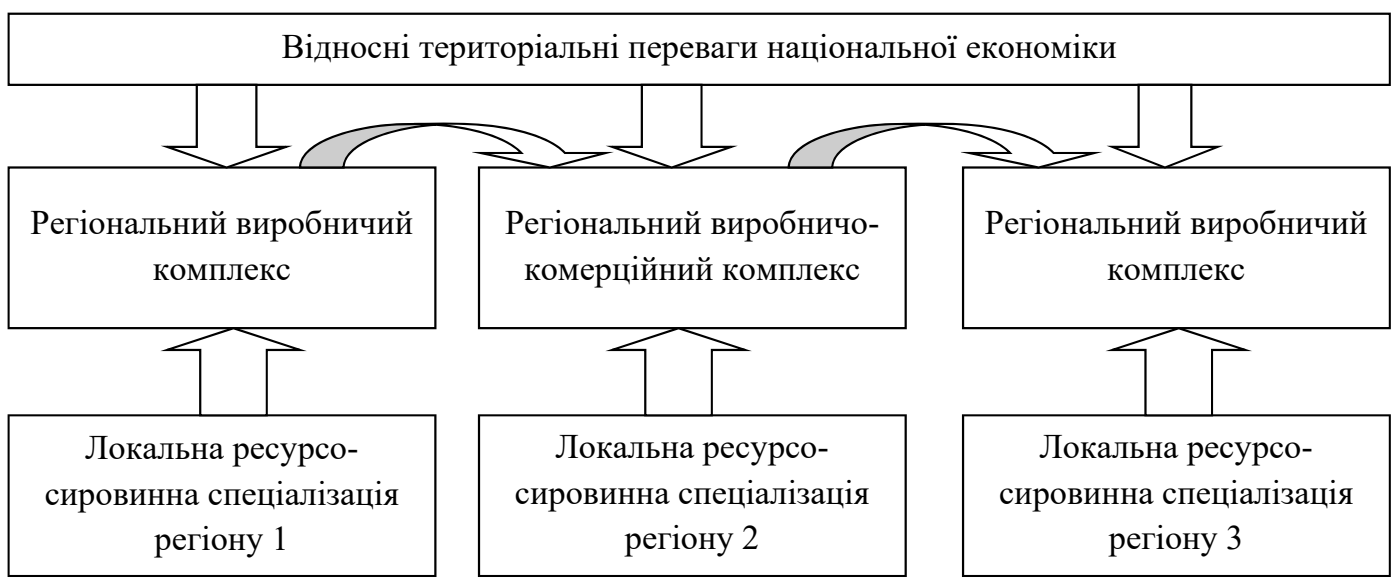

Рисунок 1 - Регіональні виробничі комплекси як основа формування територіальних конкурентних переваг 
Таблиця 2 - Загальний обсяг капітальних інвестицій за регіонами України у період 2010-2019 рр. (млн грн)

\begin{tabular}{|l|c|c|c|c|c|c|}
\hline \multirow{2}{*}{\multicolumn{1}{|c|}{ Область }} & \multicolumn{7}{c|}{ роки } \\
\cline { 2 - 7 } & $\mathbf{2 0 1 0}$ & $\mathbf{2 0 1 5}$ & $\mathbf{2 0 1 6}$ & $\mathbf{2 0 1 7}$ & $\mathbf{2 0 1 8}$ & $\mathbf{2 0 1 9}$ \\
\hline Вінницька & 3545 & 7373 & 8302 & 11744 & 17627 & 15725 \\
\hline Волинська & 1767 & 6167 & 6384 & 7042 & 8687 & 12664 \\
\hline Дніпропетровська & 16017 & 25920 & 33169 & 42908 & 60289 & 66951 \\
\hline Донецька & 14994 & 8304 & 11902 & 17269 & 26979 & 30594 \\
\hline Житомирська & 2011 & 4044 & 5573 & 7722 & 8742 & 8467 \\
\hline Закарпатська & 2205 & 3778 & 4663 & 5624 & 7501 & 9330 \\
\hline Запорізька & 7964 & 7794 & 11040 & 15880 & 15732 & 14877 \\
\hline Івано-Франківська & 4379 & 9609 & 7948 & 9708 & 9394 & 9306 \\
\hline Київська & 11331 & 24359 & 33411 & 34494 & 40713 & 50296 \\
\hline Кіровоградська & 2123 & 4057 & 6355 & 7321 & 7181 & 7794 \\
\hline Луганська & 5646 & 2060 & 4122 & 3330 & 3219 & 3358 \\
\hline Львівська & 8830 & 13387 & 18605 & 24106 & 28996 & 31062 \\
\hline Миколаївська & 4422 & 5990 & 9730 & 11178 & 10099 & 12549 \\
\hline Одеська & 9724 & 9984 & 16729 & 22300 & 23788 & 21080 \\
\hline Полтавська & 6289 & 8338 & 15265 & 15855 & 18637 & 23005 \\
\hline Рівненська & 1937 & 4334 & 4324 & 6127 & 7228 & 6729 \\
\hline Сумська & 2188 & 3663 & 5763 & 6947 & 7750 & 7734 \\
\hline Тернопільська & 2138 & 3828 & 4888 & 7151 & 8375 & 9210 \\
\hline Харківська & 8063 & 11247 & 16546 & 19362 & 23551 & 22875 \\
\hline Херсонська & 1891 & 3107 & 4591 & 7362 & 8853 & 12368 \\
\hline Хмельницька & 2948 & 6809 & 9123 & 10500 & 11275 & 10534 \\
\hline Черкаська & 2831 & 4486 & 6499 & 8144 & 11110 & 11386 \\
\hline Чернівецька & 1715 & 2789 & 2669 & 2992 & 3721 & 4097 \\
\hline Чернігівська & 1891 & 3550 & 5319 & 7351 & 8971 & 8740 \\
\hline
\end{tabular}

Джерело: побудовано автором на основі [6]

діл обсягів капітальних інвестицій у промисловість за регіонами України, який представлено на рис. 2.

Із рис. 2 ми бачимо, що капітальні інвестиції у промисловість формують основу стратегічної економічної політики регіону, що полягає у прирості відносних конкурентних переваг та мінімізації переваг абсолютного характеру. Це означає, що відбувається раціональне примноження конкурентних переваг і тим самим зростання економічного рейтингу певного регіону.

Сучасна територія як локалізована система виробництва в аспекті іiі міжрегіональної характеристики перетворилася на систему порівняльних конкурентних переваг, міра реалізації яких формує міжрегіональний статус даної території. У безпосередній практиці регіональні переваги представлені сукупністю територіально-регіональних виробничих комплексів, продуктова спеціалізація яких формує економічне профілювання регіонального виробництва [7, с. 67]. Поряд із виробничими регіональними комплексами до відносних конкурентних переваг регіону належать і його інфраструктурні елементи: підприємництво, інвестиції та фінанси, які сприяють використанню основних ресурсів регіону й інвестицій за рахунок власних коштів підприсмств (рис. 3).

Регіональні конкурентні переваги доцільно згрупувати за трьома сегментами економіки відповідно до визначеної предметної спеціалізації вироблених благ.

Першу групу конкурентних регіональних переваг утворюють техніко-технологічні переваги даного регіону, які безпосередньо пов'язані з виробництвом матеріальних цінностей.
Другу групу конкурентних регіональних переваг утворює мінімізація трансакційних витрат у реалізації так званих «невидимих» статей торгівлі (до яких сучасна економічна теорія відносить послуги і працю).

Третю, особливо важливу і динамічну, групу конкурентних регіональних переваг утворюють переваги, пов'язані з наданням послуг у сфері інтелектуальноінформаційної діяльності [8; 9].

Відносні територіальні конкурентні переваги характеризуються певною динамікою, оскільки з часом можна перевести регіональне виробництво на менш витратні, на більш екологічно безпечні і на більш капіталомісткі види виробництва. У цьому процесі алгоритм має такий вигляд: реструктуризація регіонального виробництва $\rightarrow$ алокація базових ресурсів $\rightarrow$ домінування в системі імпортно-експортних зв’язків між регіонами.

В Україні, де регіональний чинник має істотне значення, доцільним стає формування особливих «міжрегіональних зон вільної торгівлі», які стимулюють створення і забезпечують реалізацію відносних територіальних конкурентних переваг. Нині практика конкурентного протистояння виробників істотно відрізняється за ступенем організаційної та фінансової складності від форм, методів та інструментів конкурентної боротьби на попередніх етапах економічного розвитку. Саме це актуалізує загальне розроблення проблем формування та реалізації відносних конкурентних переваг, особливо на регіональному рівні.

Традиційна схема формування і реалізації відносних конкурентних переваг регіону зводиться до 


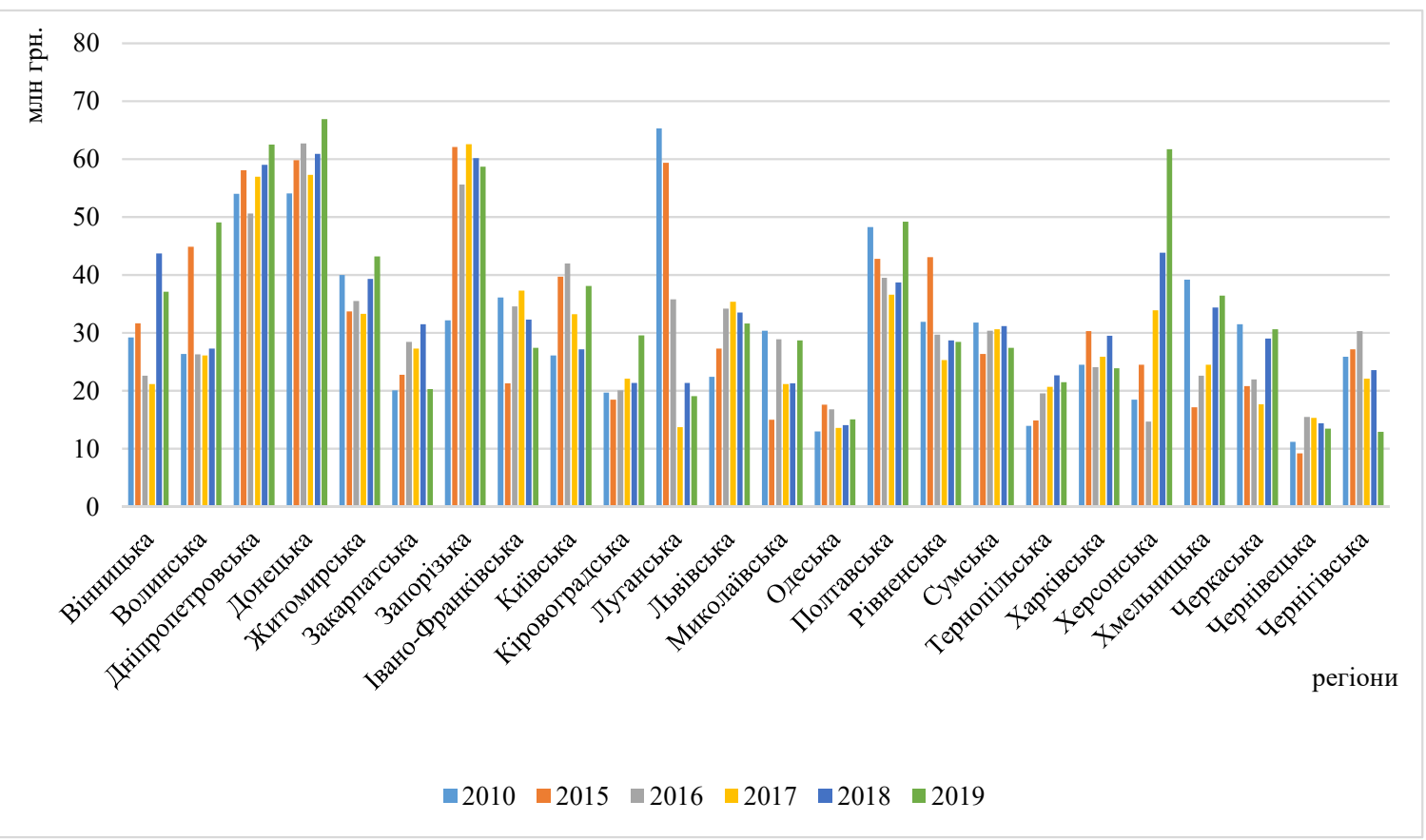

Рисунок 2 - Обсяги капітальних інвестицій у промисловість за регіонами України у період 2010-2019 рр. (млн грн)

Джерело: побудовано автором на основі [6]

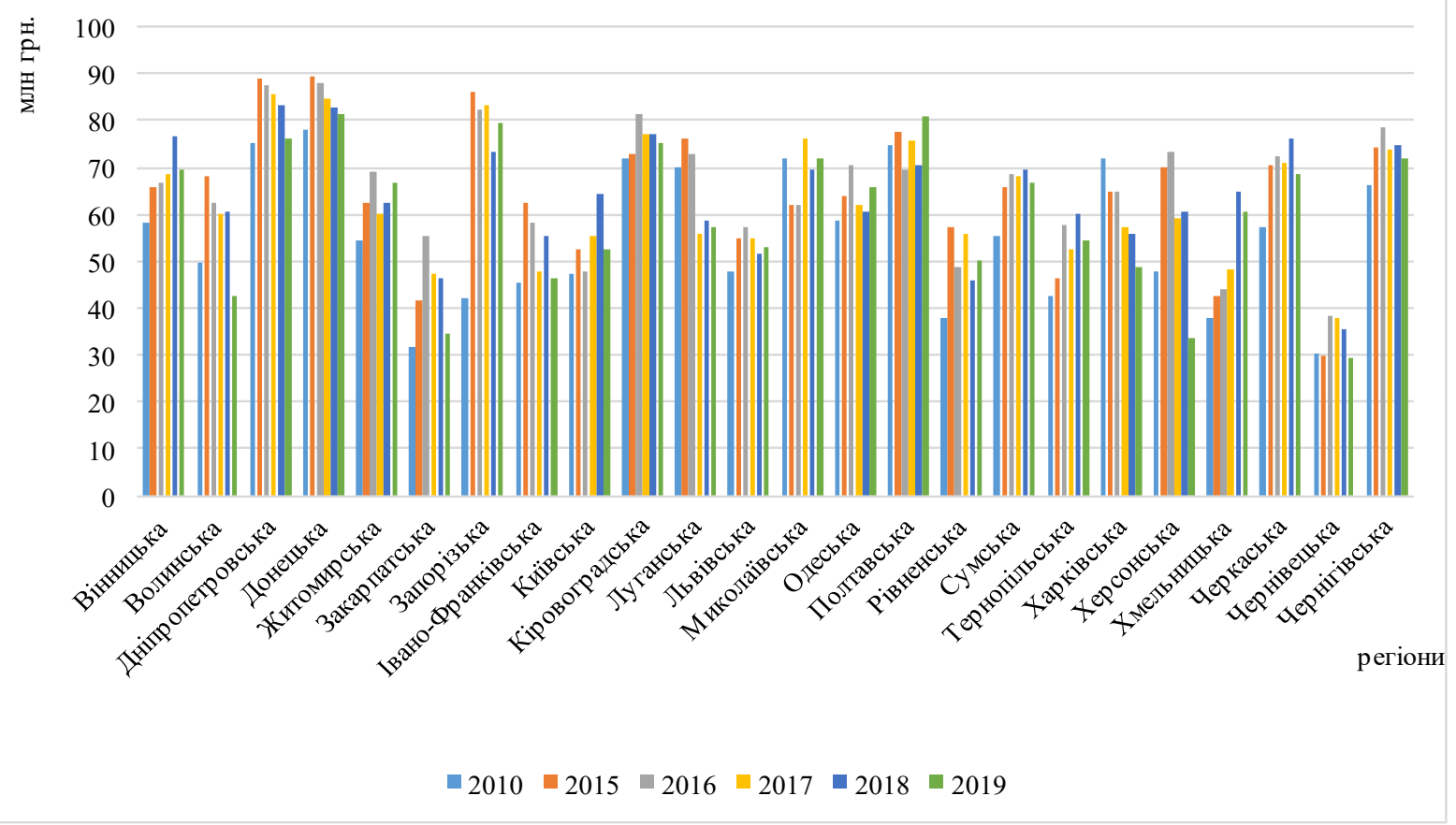

Рисунок 3 - Формування капітальних інвестицій за рахунок власних коштів підприсмств та організацій за регіонами України у період 2010-2019 рр. (млн грн)

Джерело: побудовано автором на основі [6]

більш ефективного розподілу базових чинників регіонального виробництва. Це породжує тенденцію до звуження багатогалузевого діапазону виробництва в даному регіоні, його спеціалізації та профілізації, визначення стратегічних пріоритетів у сфері міжре- гіонального партнерства. У такій ситуації оцінка рентабельності і перспектив регіонального виробництва як найважливішого доданка територіальної відносної конкурентної переваги стає домінуючою компонентою серед інструментів регіонального управління. 
Використання визначеного вище підходу дає змогу виділити регіони з високою концентрацією територіальних переваг. Йдеться про такі регіони, яким властиві наявність значної кількості динамічно зростаючих за обсягом локальних ринків, постійна акумуляція вихідних природних і трудових ресурсів, здатність активного залучення додаткових фінансових ресурсів на основі формування сприятливого інвестиційного клімату в регіоні, висока віддача інвестованого капіталу. Регіони $з$ таким рівнем конкурентних переваг зазвичай протистоять національній економічній політиці [10].

Менш сильними конкурентними перевагами характеризуються регіони, де існують обмеження у вигляді повільно зростаючих за обсягом і номенклатурою регіональних ринків. Це істотно обмежує їхні економічні позиції в міжрегіональному суперництві. Найменш ж удалі позиції тих регіонів, де економіка представлена повільно зростаючими регіональними ринками, які не мають джерел формування достатніх фінансових коштів для задоволення внутрішньорегіональних потреб в економічному розвитку і тому не мають ясних перспектив динаміки.

Дійсно, зниження регіональних витрат виробництва (і на цій основі й цін на регіональну продукцію) за допомогою розширення масштабів регіональної економіки і застосування новітніх технологій сприяє концентрації фінансових ресурсів для цілей реновації i реінвестування. Водночас продуктова диференціація дає змогу поряд із мінімізацією витрат зберегти свою присутність у певних секторах міжрегіонального ринкового простору. В аспекті регіональних виробничих комплексів розглянутий підхід дає змогу концентрувати ресурси на створенні певного спеціалізованого виробництва, яке стало б ключовим елементом у формуванні відносної конкурентної переваги регіону. Однак ця стратегія виправдана в довгостроковому аспекті, оскільки кон'юнктурна зміна ситуації вимагає більш оперативної реакції.

У короткостроковому аспекті конкурентна стратегія регіону повинна складатися з переваг стратегічного походження. Отже, йдеться про стратегію, яка передбачає формування системи односторонніх переваг. Регіону необхідно відшукати таку спеціалізовану ринкову нішу, яка б забезпечила прискорений розвиток його інвестиційно-інноваційної сфери. Необхідно інтенсифікувати виробничі і невиробничі зв'язки з регіонамипартнерами, відкрити для них пільговий доступ до ресурсів регіону.

Аналізуючи відносні конкурентні переваги в територіальному аспекті, слід мати на увазі, що сфера конкурентного суперництва тут охоплює як усі сегменти оптового, так і всі сегменти роздрібного ринку. При цьому конкурентна перевага часто залишається за тими регіонами, які забезпечують «точкове» відкриття свого ринкового простору. Методичною основою оцінки відносної конкурентоспроможності того чи іншого регіону України є так звана «факторна концепція конкурентоспроможності», коли пріоритетне значення надається зовнішнім по відношенню до даного регіону умовам і факторинговим компаніям (які елімінують макро-, мезо- і мікроекономічному політику). Правомірність факторного підходу пояснюється тією обставиною, що основна частина територіально-конкурентних переваг більшості регіонів України все ще носить природно-ресурсний характер, безпосередньо визначаючи технологічні умови та можливості здійснення виробничої діяльності в регіоні. У результаті важливим складником відносних конкурентних переваг регіону стає більша або менша залежність його економіки від сталості попиту на імпорт технології та обладнання з боку інвестиційного комплексу регіонів-імпортерів [11, с. 81-82]. Тим часом розміри інвестиційного комплексу програмують стратегічні параметри потенційного обсягу регіонального виробництва. Це тим більш важливо відзначити, що природно-ресурсні конкурентні переваги регіонів не обов'язково носитимуть характер нічим не потривоженої абсолютної переваги: можливості сучасної технології здатні перевести цю абсолютну перевагу в розряд відносної.

Звідси випливає, що в регіонах повинна усвідомлено проводитися економічна політика консервації наявних ресурсних переваг, інтенсивно заміщаючи їх відносними перевагами. Тільки у цьому разі можлива втрата ресурсних переваг регіону компенсуватиметься формуванням нових відносних конкурентних переваг. До таких переваг слід передусім віднести організацію виробництва продукції і послуг із високою доданою вартістю. У результаті динаміка зміни структури експорт зміщується в бік продукції, яка піддається багатостадійній глибокій переробці, що підсилює відносні конкурентні переваги регіону.

Не менш важливим $є$ формування територіальних конкурентних переваг у результаті концентрації зовнішніх інвестицій, залучаючи іноземні технології високої капіталомісткості, а також забезпечуючи високу мобільність регіонально-галузевому капіталу. Сьогодні $є$ всі підстави вважати, що нарощування мобільності виробничих ресурсів у регіоні становить основний інструмент у сфері здійснення міжрегіональних конкурентних переваг. Слід також ураховувати, що хоча низька норма рентабельності продукції деяких видів виробництв і становить певну конкурентну перевагу, проте для його реалізації потрібен продаж значних обсягів продукції, і тільки у цьому разі можливі ефективність і прибуток. Однак переорієнтація на товари, що мають високу норму прибутку, не завжди виправдана, оскільки у цьому разі зменшуються обсяги продажів.

До чинників, що знижують конкурентні переваги території, відноситься масове виробництво на її території продукції з коротким життєвим циклом. Однак цей недолік можна компенсувати, якщо така продукція виходить на стабільні сегменти ринку, що подовжує іiі життєвий цикл. Узагальнюючи практику, можна стверджувати, що сьогодні виникають переваги змішаного типу, які поєднують окремі параметри відносних i абсолютних переваг. В умовах гострої боротьби за переділ регіональних ринків стає скрутною альтернативна класифікація регіональних конкурентних переваг [12]. У практичному аспекті міжрегіональне економічне співробітництво можна трактувати як взаємодію 3 різними територіальними відносними перевагами. На цій основі й виникає функціональний розподіл праці в міжрегіональному виробничому просторі. 
Таблиця 3 - Структурна модель визначення регіональних конкурентних переваг

\begin{tabular}{|c|c|c|}
\hline $\begin{array}{c}\text { Параметри } \\
\text { конкурентної } \\
\text { переваги }\end{array}$ & Зміст конкурентної переваги & $\begin{array}{c}\text { Практичні аспекти реалізації } \\
\text { конкурентної переваги }\end{array}$ \\
\hline \multirow{3}{*}{$\begin{array}{l}\text { Форми } \\
\text { вираження }\end{array}$} & природні ресурси регіону & профільовані регіональні виробничі комплекси \\
\hline & рівень і кваліфікація робочої сили & конкурентоздатна якість регіональної продукції \\
\hline & економічна організація регіонального виробництва & $\begin{array}{l}\text { мінімізація прямих і непрямих витрат регіонального } \\
\text { виробництва }\end{array}$ \\
\hline \multirow{3}{*}{$\begin{array}{l}\text { Сфери } \\
\text { реалізації }\end{array}$} & виробнича & висока технологія \\
\hline & соціальна & якість життя \\
\hline & фінансова & інвестиційна місткість виробництва \\
\hline \multirow{4}{*}{$\begin{array}{l}\text { Суб'єктна } \\
\text { характеристика }\end{array}$} & виробнича організація & корпоративна структура \\
\hline & регіон & адміністративна синергетика \\
\hline & галузь & монопроіфльне виробництво \\
\hline & сфера & монопроіфльний простір \\
\hline \multirow{2}{*}{ Джерела } & внутрішньорегіональні & локальна сукупність унікальних властивостей \\
\hline & надрегіональні & макроекономічні властивості виробничої системи \\
\hline \multirow{2}{*}{$\begin{array}{l}\text { Системні } \\
\text { властивості }\end{array}$} & кількісна оцінка & $\begin{array}{l}\text { натурально-речова структура регіонального } \\
\text { валового продукту }\end{array}$ \\
\hline & якісна оцінка & $\begin{array}{l}\text { конкурентоздатні технології виробництва, рівень } \\
\text { витрат, величина трансакційних витрат }\end{array}$ \\
\hline
\end{tabular}

Джерело: розроблено автором

У внутрішньорегіональному співвідношенні конкурентних переваг пропорція між абсолютними і відносними перевагами не залишається постійною. Хоча для більшості регіонів України їхні абсолютні конкурентні переваги зумовлені присутністю унікальних природно-природних ресурсів і можливостей їх виробничого використання в межах того чи іншого регіону. Проте й абсолютні переваги можуть під впливом новий технологічних досягнень утратити свій абсолютний статус і трансформуватися у відносну перевагу.

Може змінитися геостратегічне положення регіону у зв'язку з відкриттям нових транспортних шляхів, можуть вичерпатися мінеральні ресурси тощо. У міжрегіональній економічній конкуренції можна виділити кілька рівнів: внутрішньодержавна конкуренція економічно відокремлених територій, конкуренція регіонів однієї країни з регіонами іншої країни, внутрішньорегіональна конкуренція. Базовим рівнем даної сфери виступають міжрегіональні конкурентні процеси. Звичайно, масштаби і наслідки міжрегіональної конкуренції визначаються ефективністю вільного пересування ресурсів, товарів і фінансів, а також робочої сили. У стратегічній перспективі практично будь-який регіон здатний вийти на сталий конкурентоспроможний рівень розвитку допомогою цілеспрямованого формування стійкої відносної конкурентної переваги.

Регіональна економічна політика, спрямована на формування відносних конкурентних переваг окремої території, має надзавдання - прискорений розвиток наявних і залучення додаткових ресурсів природного, інвестиційного та інноваційного характеру для досягнення профіцитного рівня доходів регіону. Конкретні «точки» відносних переваг території можуть бути такими:
- реалізація довгострокових масштабних міжрегіональних інвестиційних проєктів;

- гарантія довгострокового збереження пільгового оподаткування прямих позарегіональних інвестицій;

- вільний доступ інвесторів до ресурсів регіону.

Викладене вище дає змогу сформувати структуру регіональних конкурентних переваг (табл. 3).

Запропонована схема структурування відносних економічних переваг регіону, як нам уявляється, дає змогу відобразити найбільш суттєві властивості на територіальному рівні і може бути покладена в основу їх перспективної класифікації.

Висновки. Регіони України фактично увійшли як невід'ємний елемент у глобальні зв'язки світової економіки. Тому конкурентоспроможність регіонів визначається можливістю їх стабільної присутності на певних сегментах глобального ринку. Своєю чергою, відкритість лібералізованої української економіки трансформувала економіку країни у складову частину світогосподарської системи. Особливу відкритість демонструють первинні стратегічні економічні суб'єкти, до яких відносяться національні корпорації транснаціонального рівня. Чим ефективніше виробництво в таких національно-транснаціональних корпораціях, тим ефективніше механізм міждержавного співробітництва, тим важливіше технології виробництва і переробки, а не природні ресурси. Визначено, що надзавдання регіонів - не природні ресурси «проїдати», безвідповідально і наївно вважаючи, що дароване природою й утворює їхню конкурентну перевагу, а перетворювати своє регіональне виробництво на економічний механізм, що створює найголовніше у сучасній конкурентній боротьбі - додану вартість. Тільки величина доданої вартості в структурі ціни регіонального валового продукту здатна об'єктивно свідчити про реальний рівень конкурентоспроможності застосовуваної технології. 


\section{Список використаних джерел:}

1. Перский Ю.К., Калюжнова Н.Я. Конкурентоспособность регионов: теоретико-прикладные аспекты. Москва : ТЕИС, 2013. 334 c.

2. Carron G. Strategic Planning. Concept and rationale. Washington : UNESCO, 2010. 25 p.

3. Дегтярьова I.O. Фактори підвищення конкурентоспроможності сучасного регіону. URL: http://www. academy.gov.ua/ej/ ej9/doc_pdf/Degtyareva_IO.pdf (дата звернення: 05.02.2021).

4. Ряба О.І., Шумило Н.М. Конкурентоспроможність України та напрями ії̈ підвищення. Вісник Хмельницького національного університету. 2010. № 2. Т. 3. С. 44-47.

5. Бутко Н., Подоляк Л. Державне регулювання як інструмент підвищення конкурентоспроможності регіонів. Економіка Украӥни. 2012. № 6. С. 36-44.

6. Статистичний щорічник України за 2019 р. / за ред. I.Є. Вернер. Київ : Державна служба статистики України, 2019. $309 \mathrm{c}$.

7. Безверхнюк Т.М. Ресурсне забезпечення регіонального управління: теоретико-методологічні засади : монографія. Одеса : ОРІДУ НАДУ, 2009. 320 с.

8. Білик В.В. Стратегія управління конкурентними перевагами регіону. Економіка та суспільство. 2018. № 19. С. 9-19.

9. Про затвердження Порядку розроблення, проведення моніторингу та оцінки реалізації регіональних стратегій розвитку : Постанова Кабінету Міністрів України від 16 грудня 2011 р. № 1186. Київ : Україна. 2011. № 91. С. 126. Ст. 3294.

10. Данилишин Б. Регионализм в Украине: реальность и перспективы. Зеркало недели. 2012. № 22. С. 6-7.

11. Metelenko N.G., Kovalenko O.V., Makedon V.V., Merzhynskyi Y.K., Rudych A.I. Infrastructure security of formation and development of sectoral corporate clusters. Journal of Security and Sustainability Issues. 2019. № 9(1). P. 77-89. DOI: http://doi.org/10.9770/jssi.2019.9.1(7).

12. Конкурентні переваги промислового сектора економіки України: регіональний вимір : монографія / наук. редактор д.е.н., проф. С.О. Іщук. Львів, 2018. 246 с.

\section{References:}

1. Persky Yu.K., Kalyuzhnova N.Ya. Konkurentosposobnost' rehyonov: teoretyko-prykladnye aspekty [Competitiveness of regions: theoretical and applied aspects]. Moscow, TEIS. (in Russian)

2. Carron G. (2010) Strategic Planning. Concept and rationale. Washington : UNESCO

3. Degtyareva I.O. (2020) Faktory pidvyshchennya konkurentospromozhnosti suchasnoho rehionu [Factors for increasing the competitiveness of the modern region]. Available at: http://www.academy.gov.ua/ej/ej9/doc_pdf/Degtyareva_IO.pdf (accessed 05 February 2021).

4. Ryaba O.I., Shumylo N.M. (2010) Konkurentospromozhnist' Ukrayiny ta napryamy yiyi pidvyshchennya [Competitiveness of Ukraine and directions of its improvement]. Bulletin of Khmelnitsky National University, vol. 2, no. 3, pp. 44-47.

5. Butko N., Podoliak L. (2012) Derzhavne rehulyuvannya yak instrument pidvyshchennya konkurentospromozhnosti rehioniv [State regulation as a tool to increase the competitiveness of regions]. Ukraine economy, no. 6, pp. 36-44.

6. Statistical Yearbook of Ukraine for 2019 (2019) Statystychnyy shchorichnyk Ukrayiny za 2019 r. [State Statistics Service of Ukraine]. State Statistics Service of Ukraine. (in Ukrainian)

7. Bezverkhnyuk T.M. (2009) esursne zabezpechennya rehional'noho upravlinnya: teoretyko-metodolohichni zasady [Resource support of regional management: theoretical and methodological principles: monograph]. Odessa: ORIDU NADU. (in Ukrainian)

8. Bilyk V.V. (2018) Stratehiya upravlinnya konkurentnymy perevahamy rehionu [Regional competitive advantage management strategy]. Economy and society, vol. 19, pp. 9-19.

9. On approval of the Procedure for development, monitoring and evaluation of the implementation of regional development strategies (2011) Postanova Kabinetu Ministriv Ukrayiny [Resolution of the Cabinet of Ministers of Ukraine]. № 1186. Ukraine Publishing House. (in Ukrainian)

10. Danilishin B. (2012) Rehyonalyzm v Ukrayne: real'nost' y perspektyvy [Regionalism in Ukraine: reality and prospects]. Mirror of the week, no. 22, pp. 6-7.

11. Metelenko N.G., Kovalenko O.V., Makedon V.V., Merzhynskyi Y.K., Rudych A.I. (2019) Infrastructure security of formation and development of sectoral corporate clusters. Journal of Security and Sustainability. Issues, 9(1), pp. 77-89. DOI: http://doi.org/10.9770/jssi.2019.9.1(7)

12. Ishchuk S.O. (2018). Konkurentni perevahy promyslovoho sektora ekonomiky Ukrayiny: rehional'nyy vymir [Competitive advantages of the industrial sector of the economy of Ukraine: regional dimension: monograph]. SI "Institute of Regional Studies named after MI Dolny National Academy of Sciences of Ukraine, Lviv. (in Ukrainian)

Nesterenko Svetlana

Open International University of Human Development "Ukraine"

\section{ACTUALIZATION OF THE PROCESS OF ACCELERATED FORMATION OF RELATIVE COMPETITIVE ADVANTAGES OF THE REGIONS OF UKRAINE}

The article examines the theoretical and applied principles of formation of competitive advantages of the mesolevel of the national economy in terms of accelerating the formation of relative competitive advantages of the regions of Ukraine. A structural hierarchy of relative competitive advantages within the national economy was formed. An analysis of the provision of capital investment in the regions of Ukraine in terms of industry and the main sources of their formation. A structural model for determining regional competitive advantages has been developed. It is proved that the formation and development of regional production complexes contributes to the realization of territorial competitive advantages, which stimulates economic growth of regions on the basis of their active entry into the world 
economy, as well as interregional division of social and production functions between regions. It is determined that the formation of regional production complexes reflects the objective differences of the regions, which are represented by a set of these complexes, integratedly represent the territorial competitive advantages. It is proved that the modern territory as a localized system of production was transformed into a system of territorially connected regional production complexes, based on the integration of business, investment and financial infrastructures of the region. It was substantiated the scientific position that each regional production complex is formed on the basis of basic resource elements of the region, which contributes to the realization of its objective competitive advantages. Since each regional production complex is a separate element of the system of interregional division of labor within the national macroeconomy, the competitive advantages of the territory reflect the features of industrial specialization and the level of interregional cooperation. At present, there is a reorientation of macro-financial flows towards the regions of the territories, which provide more competitive conditions for the development of long-term capital investments. It follows that the totality of regional production complexes represents the actual range of their territorial relative competitive advantages.

Key words: competitive advantages, regional production complexes, meso level, capital investments, industry, regional production.

JEL classification: E23, H54, L50 